\title{
Hubungan Preferensi Harga dan Merk Terhadap Pemilihan Hospital Bed
}

\author{
Adryan Henry Soetedjo, Ho Fransiscus Alexander Setiadi, Mohammad \\ Febby Ardhani, Oktavianus Andika Prastyanto, Reza Budi Satria
}

School of Business and Economics Universitas Prasetiya Mulya

JL. RA. Kartini (TB Simatupang), Cilandak Barat Jakarta Selatan, Jakarta 12430 Indonesia.

*. Corresponding Author: oktandika@gmail.com

\begin{tabular}{|c|c|}
\hline Abstract & \\
\hline $\begin{array}{l}\text { Hospital bed is a type of health equipment used in almost all } \\
\text { types of health facilities. Along with the development of the } \\
\text { BPJS program, new health facilities that require hospital } \\
\text { beds are also increasing in number. In hospital bed } \\
\text { procurement, health facilities need to consider several } \\
\text { factors, including price and brand. Based on this, a survey } \\
\text { was conducted on } 41 \text { health facilities to identify these two } \\
\text { factors using explanatory research. The survey data were } \\
\text { processed using Microsoft Excel } 2016 \text { and IBM SPSS } 22.0 \\
\text { software resulted in a Pearson correlation of } 0.108 . \\
\text { Statistical tests were performed using bivariate correlations, } \\
\text { which shows a weak linear correlation between price and } \\
\text { brand factors. }\end{array}$ & \multirow[t]{3}{*}{$\begin{array}{l}\text { Keywords: hospital bed, } \\
\text { price preferences, brand } \\
\text { preferences, health } \\
\text { facilities, explanatory } \\
\text { research }\end{array}$} \\
\hline Abstrak & \\
\hline $\begin{array}{l}\text { Tempat tidur rumah sakit atau yang disebut juga dengan } \\
\text { hospital bed adalah jenis alat kesehatan yang dipakai } \\
\text { hampir di semua jenis fasilitas kesehatan. Seiring dengan } \\
\text { pengembangan program BPJS, maka fasilitas kesehatan } \\
\text { baru yang membutuhkan hospital bed juga meningkat } \\
\text { jumlahnya. Dalam pengadaan hospital bed, fasilitas } \\
\text { kesehatan perlu mempertimbangkan beberapa faktor, } \\
\text { diantaranya adalah harga dan merk. Berdasarkan hal } \\
\text { tersebut, survey diadakan terhadap } 41 \text { fasilitas kesehatan } \\
\text { untuk mengidentifikasi kedua faktor tersebut menggunakan } \\
\text { explanatory research. Data hasil survey diolah } \\
\text { menggunakan software Microsoft Excel } 2016 \text { dan IBM SPSS } \\
22.0 \text { menghasilkan pearson correlation sebesar } 0.108 \text {. Uji } \\
\text { statistik dilakukan menggunakan korelasi bivariate yang } \\
\text { menunjukkan korelasi linear yang lemah antara faktor harga } \\
\text { dan merk. }\end{array}$ & \\
\hline
\end{tabular}




\section{PENDAHULUAN}

Sejak tahun 2015, Indonesia mulai fokus mengembangkan program kesehatan. Salah satu langkah yang diambil pemerintah yaitu dengan menyiapkan program BPJS untuk masyarakat. Dengan adanya program BPJS, maka setiap warga negara mempunyai kesempatan untuk mendapatkan jaminan kesehatan yang layak.

Untuk mendukung program BPJS, pengembangan di sektor fasilitas kesehatan juga harus dilakukan. Hospital bed merupakan salah satu jenis alat kesehatan yang dibutuhkan setiap rumah sakit dan fasilitas kesehatan lainnya. Seiring dengan dikembangkannya jumlah fasilitas kesehatan, kebutuhan akan ketersediaan hospital bed yang memadai juga meningkat.

Berdasarkan data Kementerian Kesehatan, jumlah hospital bed di fasilitas kesehatan baik swasta maupun pemerintah di tahun 2017 telah mencapai 338.691. Jika dibandingkan data tahun 2013 dimana jumlah hospital bed berjumlah 278.450 unit, maka CAGR dari tahun 2013 sampai tahun 2017 adalah 4.7\%. Maka diproyeksikan hingga tahun 2023, jumlah hospital bed yang dibutuhkan di Indonesia akan mencapai 440.735 unit.

Dari data-data di atas, ada peluang bagi produsen alat kesehatan untuk mencoba memenuhi kebutuhan hospital bed. Produk hospital bed yang mudah didistribusikan bisa menjadi solusi. Jurnal ini bertujuan mengidentifikasi apakah faktor preferensi 
harga dan preferensi merk mempengaruhi pemilihan hospital bed oleh konsumen, dalam hal ini secara spesifik adalah fasilitas kesehatan.

\section{TINJAUAN PUSTAKA}

Harga seringkali dipakai sebagai tolok ukur atas suatu produk ataupun jasa dan dihubungkan dengan manfaat dan kepuasan atas konsumsi produk maupun jasa tersebut. Menurut Kotler dan Armstrong (2008), harga didefinisikan sebagai sejumlah uang yang dibebankan pada suatu produk dan jasa, atau sejumlah nilai yang ditukar oleh konsumen atas manfaat-manfaat dari kepemilikan dan penggunaan suatu produk dan jasa.

Indikator harga menurut Kotler dan Keller (2012) adalah:

1. Keterjangkauan harga

2. Kesesuaian harga dengan kualitas produk

3. Daya saing harga

4. Kesesuaian harga dan manfaat produk

5. Pengaruh harga terhadap daya beli konsumen

6. Pengaruh harga terhadap keputusan pembelian konsumen

Persepsi masyarakat terhadap suatu perusahaan atau produknya disebut sebagai image, menurut Kotler dan Keller (2012). Sejalan dengan itu, citra merk adalah bagaimana suatu merek mempengaruh persepsi konsumen terhadap produk atau 
perusahaan tersebut. Reputasi perusahaan dipengaruhi oleh citra merek yang positif sebagai hasil dari konsistensi, kredibilitas dan pengalaman yang dinamis.

Menurut penelitian Dharma \& Sukaatmaja (2015), citra merk memiliki hubungan linear terhadap keputusan pembelian konsumen. Persepi konsumen dan keputusan pembelian mereka dapat ditingkatkan melalui pengalaman pembelian masa lalu dan keakraban dengan merek. (Aaker, 1991).

Berdasarkan tinjauan pustaka di atas, tidak adanya keterkaitan antara preferensi harga dan preferensi merk dalam memilih hospital bed adalah hipotesis awal yang digunakan.

\section{METODOLOGI PENELITIAN}

Populasi dalam penelitian ini difokuskan pada area Jabodetabek dan karyawan yang bekerja di fasilitas kesehatan berupa rumah sakit maupun selain rumah sakit.

Metode survei digunakan dalam penelitian ini di mana pengumpulan datanya dilakukan dengan menggunakan kuesioner. Kuesioner adalah kumpulan pertanyaan yang dibuat dalam bentuk formulir untuk memperoleh informasi dari responden. Media yang digunakan untuk membuat kuesioner adalah Google Form.

Pengujian hipotesis atau penelitian penjelasan (explanatory research) dilakukan di dalam survei ini. Format eksplanatori bertujuan untuk menjelaskan suatu generalisasi 
sampel terhadap populasinya, atau menjelaskan hubungan, perbedaan atau pengaruh suatu variabel dengan variabel lain (Bungin, 2005).

Data primer dalam penelitian ini diperoleh dengan menggunakan pendekatan kuantitatif dengan metode survei yang menggunakan kuesioner yang ditujukan kepada fasilitas kesehatan. Studi literatur juga dilakukan mengenai perkembangan fasilitas kesehatan dan preferensi konsumen terhadap suatu barang atau jasa. Literatur yang dijadikan referensi antara lain berupa dokumen laporan yang berkaitan dengan topik penelitian, buku teks dan jurnal.

Pengolahan data hasil kuesioner dilakukan dengan menggunakan software Microsoft Excel 2016 dan IBM SPSS 22.0 for Windows. Analisis data kuantitatif dilakukan dengan tahap pengolahan data, penyajian data dan penarikan kesimpulan. Hasil analisis variabel yang konsisten diambil untuk dilakukan penarikan kesimpulan hasil penelitian.

\section{ANALISIS DATA}

Dari hasil survei penelitian, pengambilan sampling secara acak terhadap populasi fasilitas kesehatan yang berada di area Jabodetabek menghasilkan 41 responden.

Dengan menggunakan kuesioner, penilaian mandiri dilakukan oleh responden untuk menilai faktor-faktor preferensi yang dijadikan pertimbangan dalam memilih hospital 
bed. Hasil survei menyatakan bahwa $65.9 \%$ responden mempertimbangkan preferensi harga sebagai yang utama dalam memilih hospital bed.

Sementara itu, hanya $14.6 \%$ responden yang mempertimbangkan preferensi merk dalam memilih hospital bed. Preferensi merk berada di urutan terakhir dari 5 jenis preferensi yang dinilai. Jika dikaitkan dengan preferensi harga, responden yang mempertimbangkan harga sebagai preferensi utama sebagian besar tidak memilih preferensi merk sebagai pertimbangan berikutnya yang dinilai penting.

Dari hasil penilaian responden terhadap kedua preferensi tersebut, tidak terdapat tanda-tanda keterkaitan. Selanjutnya, adanya keterkaitan yang signifikan antara preferensi harga dan preferensi merk diuji secara statistik menggunakan analisis dengan teknik korelasi bivariate. Hasil survei dari masing-masing variable preferensi digunakan sebagai data yang akan diolah.

\section{Hipotesis Awal (H0):}

Tidak adanya hubungan yang signifikan antara preferensi harga dan preferensi merk dalam memilih hospital bed.

\section{Hipotesis Alternatif (H1):}

Adanya hubungan yang signifikan antara preferensi harga dan preferensi merk dalam memilih hospital bed. 
Software IBM SPSS digunakan dalam pengolahan uji keterkaitan atau korelasi, dan menggunakan selang kepercayaan (confidence level) sebesar 95\%. Hasil pengolahan menggunakan SPSS dapat dilihat pada Tabel 1.

Tabel 1. Hasil Analisis Korelasi Bivariate menggunakan IBM SPSS

\begin{tabular}{|ll|r|r|}
\hline \multicolumn{3}{|c|}{ Correlations } \\
\hline Pref_Harga & Pearson Correlation & 1 & .108 \\
& Sig. (2-tailed) & & .501 \\
& $\mathrm{~N}$ & 41 & 41 \\
\hline Pref_Merk & Pearson Correlation & .108 & 1 \\
& Sig. (2-tailed) & .501 & \\
& $\mathrm{~N}$ & 41 & 41 \\
\hline
\end{tabular}

Dari Tabel 1, didapat hasil pearson correlation sebesar 0.108 dengan $p$-value $>0.01$. Maka dapat ditarik kesimpulan bahwa dengan selang kepercayaan 95\%, tidak cukup bukti untuk menolak Hipotesis Awal (HO) dan terdapat korelasi yang lemah antar kedua variabel, yaitu preferensi harga dan preferensi merk.

\section{KESIMPULAN}

Melihat dari latar belakang dan hasil analisis pada bagian sebelumnya, maka dapat disimpulkan bahwa merk tidak menjadi salah satu pertimbangan utama bagi fasilitas kesehatan. Jika harga yang diberikan oleh penyedia hospital bed sesuai dengan 
kualitas yang diharapkan, maka apapun merknya tidak menjadi masalah bagi fasilitas kesehatan.

Korelasi linear yang lemah antara preferensi harga dan preferensi merk juga ditunjukkan dari uji statistik korelasi bivariate. Hasil tersebut menyatakan bahwa tidak cukup bukti untuk menerima adanya hubungan yang signifikan antara preferensi harga dan preferensi merk dalam memilih hospital bed.

Dari hasil kuesioner didapat informasi bahwa fasilitas kesehatan memilih produk hospital bed yang memiliki reliability yang baik. Oleh karena itu, kualitas menjadi preferensi yang lebih diutamakan daripada preferensi merk. Dengan demikian, tidak terdapat korelasi yang linear antara preferensi harga dan preferensi merk. 


\section{DAFTAR PUSTAKA}

Bungin, Prof. Dr. H. M. Burhan, S.Sos., M.Si. (2005). Metode Penelitian Kuantitatif. Kencana.

Aaker, David A. (1991). Managing Brand Equity: Capitalizing on The Value of a Brand Name. New York: The Free Press.

Kementerian Kesehatan RI. (2017). “Profil Kesehatan Indonesia Tahun 2016." http://www.depkes.go.id/resources/download/pusdatin/profil-kesehatanindonesia/Profil-Kesehatan-Indonesia-2016.pdf diakses pada tanggal 24 Februari 2018

Kotler, P dan Armstrong, G. (2008). Prinsip-Prinsip-Pemasaran, Edisi 12, Jilid 1. Jakarta: Erlangga.

Kotler, P dan Keller, K.L. (2012). Marketing Management, 14th Edition. London: Pearson Education.

Setiawati, Elis. (2014). “Pengaruh Harga dan Citra Merek Terhadap Pembelian Televisi Samsung di Perumahan Villa Grand Tomang Tangerang." Jakarta: Universitas Esa Unggul

Surya Adi Dharma, N \& Sukaatmaja, I. (2015). "Pengaruh Citra Merek, Kesadaran Merek, dan Kualitas Produk Terhadap Keputusan Membeli Produk Apple." Badung: Universitas Udayana. 


\section{LAMPIRAN}

Grafik Rasio dan Jumlah Hospital Bed di Indonesia Tahun 2015

$$
14
$$

$350 R \mathrm{~B}$
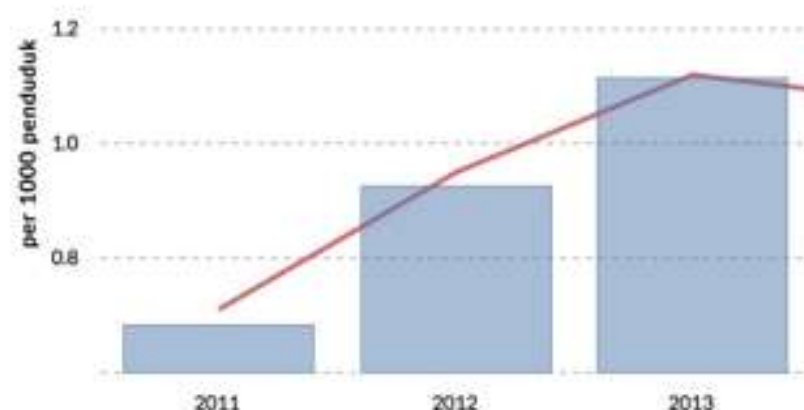

- Rasio tempat tidur RS feer 1000 penduduk?
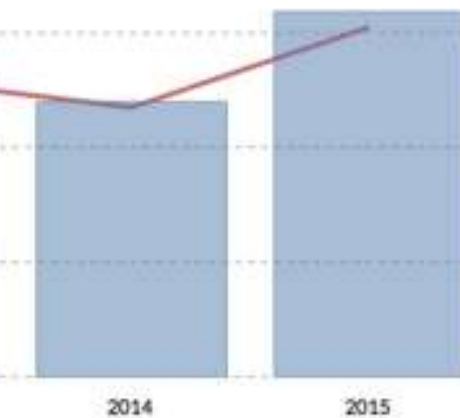

$300 R b$

$250 R \mathrm{~b}$

$200 \mathrm{Rb}$

(Source: Kementrian Kesehatan)

Hasil Survei Hospital Bed (Periode Survei: Juli 2018)

Skala $1 \quad$ : $\quad$ Sangat Tidak Penting

Skala $5 \quad: \quad$ Sangat Penting

Seberapa penting HARGA menjadi pertimbangan anda dalam memilih hospital bed?

41 responses

30

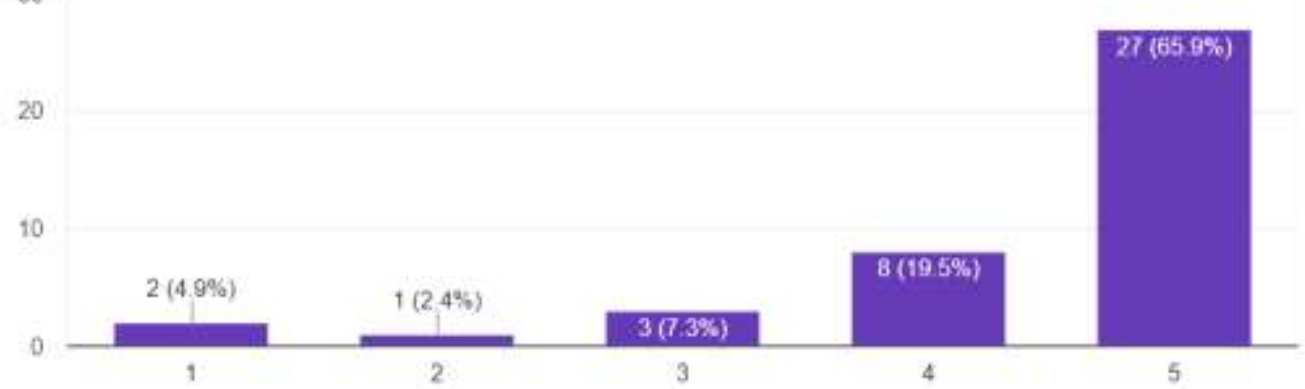


Seberapa penting MERK menjadi pertimbangan anda dalam memilih hospital bed?

41 responses

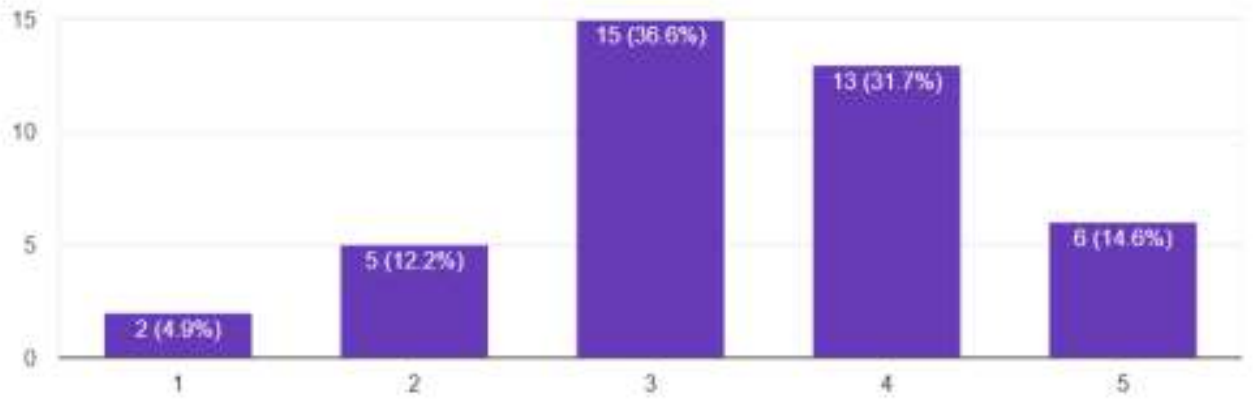


Vol.01, No. 2, 2018

\section{Datasheet Analisis Hasil Survei SPSS}

\begin{tabular}{|c|c|}
\hline Nilai & Jenis Fasilitas Kesehatan \\
\hline 1 & Rumah Sakit \\
\hline 2 & Selain Rumah Sakit \\
\hline
\end{tabular}

\begin{tabular}{|c|c|}
\hline Nilai & Jenis Karyawan Fasilitas Kesehatan \\
\hline 1 & Medis \\
\hline 2 & Non Medis \\
\hline
\end{tabular}

\begin{tabular}{|c|c|}
\hline Nilai & Tingkat Preferensi Terhadap Harga \\
\hline 0 & Skala $1-3$ \\
\hline 1 & Skala $4-5$ \\
\hline
\end{tabular}

\begin{tabular}{|c|c|}
\hline Nilai & Tingkat Preferensi Terhadap Merk \\
\hline 0 & Skala $1-3$ \\
\hline 1 & Skala $4-5$ \\
\hline
\end{tabular}

\begin{tabular}{|c|c|c|c|c|c|}
\hline \multicolumn{2}{|c|}{ Pertanyaan Survei } & \multicolumn{2}{|c|}{$\begin{array}{l}\text { Seberapa penting HARGA menjadi pertimbangan anda } \\
\text { dalam memilih hospital bed? }\end{array}$} & \multicolumn{2}{|c|}{$\begin{array}{l}\text { Seberapa penting MERK menjadi pertimbangan anda } \\
\text { dalam memilih hospital bed? }\end{array}$} \\
\hline $\begin{array}{l}\text { Jenis Fasilitas } \\
\text { Kesehatan }\end{array}$ & Jenis Karyawan & Data Hasil Survey & $\begin{array}{c}\text { Tingkat Preferensi Terhadap } \\
\text { Harga }\end{array}$ & Data Hasil Survey & $\begin{array}{c}\text { Tingkat Preferensi Terhadap } \\
\text { Merk }\end{array}$ \\
\hline 2 & 1 & 5 & 1 & 3 & 0 \\
\hline 1 & 2 & 5 & 1 & 5 & 1 \\
\hline 1 & 2 & 5 & 1 & 5 & 1 \\
\hline 2 & 2 & 4 & 1 & 4 & 1 \\
\hline 1 & 2 & 4 & 1 & 4 & 1 \\
\hline 2 & 2 & 5 & 1 & 3 & 0 \\
\hline 2 & 2 & 5 & 1 & 4 & 1 \\
\hline 1 & 2 & 5 & 1 & 3 & 0 \\
\hline 2 & 1 & 4 & 1 & 2 & 0 \\
\hline 1 & 2 & 5 & 1 & 4 & 1 \\
\hline 1 & 2 & 5 & 1 & 5 & 1 \\
\hline 1 & 2 & 5 & 1 & 2 & 0 \\
\hline 2 & 2 & 5 & 1 & 3 & 0 \\
\hline 2 & 2 & 5 & 1 & 2 & 0 \\
\hline 2 & 1 & 5 & 1 & 4 & 1 \\
\hline 1 & 2 & 2 & 0 & 2 & 0 \\
\hline 1 & 1 & 1 & 0 & 1 & 0 \\
\hline 2 & 2 & 5 & 1 & 5 & 1 \\
\hline 1 & 1 & 5 & 1 & 2 & 0 \\
\hline 2 & 1 & 4 & 1 & 4 & 1 \\
\hline 2 & 1 & 3 & 0 & 4 & 1 \\
\hline 1 & 1 & 4 & 1 & 3 & 0 \\
\hline 1 & 1 & 5 & 1 & 4 & 1 \\
\hline 2 & 1 & 4 & 1 & 3 & 0 \\
\hline 1 & 2 & 3 & 0 & 3 & 0 \\
\hline 2 & 2 & 1 & 0 & 1 & 0 \\
\hline 2 & 2 & 3 & 0 & 4 & 1 \\
\hline 2 & 2 & 5 & 1 & 3 & 0 \\
\hline 1 & 2 & 5 & 1 & 3 & 0 \\
\hline 2 & 1 & 5 & 1 & 4 & 1 \\
\hline 2 & 2 & 5 & 1 & 5 & 1 \\
\hline 2 & 2 & 5 & 1 & 4 & 1 \\
\hline 2 & 2 & 5 & 1 & 4 & 1 \\
\hline 2 & 2 & 5 & 1 & 3 & 0 \\
\hline 1 & 2 & 5 & 1 & 3 & 0 \\
\hline 1 & 1 & 5 & 1 & 3 & 0 \\
\hline 1 & 2 & 5 & 1 & 3 & 0 \\
\hline 2 & 2 & 5 & 1 & 3 & 0 \\
\hline 2 & 2 & 4 & 1 & 3 & 0 \\
\hline 1 & 2 & 5 & 1 & 5 & 1 \\
\hline 1 & 1 & 4 & 1 & 4 & 1 \\
\hline
\end{tabular}

